\title{
Narrow Row Spacing Does Not Affect Lima Bean Yield or Management of Weeds and Other Pests
}

\author{
Sujatha Sankula ${ }^{1}$, Mark J. VanGessel, and Walter E. Kee, Jr. \\ University of Delaware Research and Education Center, RR 6, Box 48, \\ Georgetown, DE 19947-9575
}

\section{Edward Beste and Kathryne L. Everts \\ University of Maryland Lower Eastern Shore Research and Education Center, Salisbury, MD 21801}

Additional index words. cultivation, economic analysis, herbicides, partial budget analysis, Phaseolus lunatus, pod rot, Rhizoctonia solani

\begin{abstract}
Potential increases in the yield of agronomic crops through enhanced light interception have led many growers to consider using narrow rows in lima bean (Phaseolus lunatus L.). However, no information is available on how narrow row spacing affects weed management or fits into an integrated pest management strategy. To address this, field studies were conducted in Delaware and Maryland in 1996 and 1997 to evaluate the effects of row spacing ( $38 \mathrm{vs} .76 \mathrm{~cm}$ ) on weed control, and on yield and quality of lima bean. Weed management inputs were also evaluated with labeled or reduced pre-emergence rates of metolachlor plus imazethapyr applied broadcast or banded. Only $76-\mathrm{cm}$ rows were cultivated according to the standard practice for this production system. In general, row spacing, herbicide rate, and herbicide application method had no effect on lima bean biomass or yield, on weed density, control, or biomass production, or on economic return. However, weed control consistency was improved when wide rows were used, even with reduced herbicide rates, possibly because of cultivation. Using reduced herbicide rates and band applications resulted in $84 \%$ less herbicide applied without affecting weed control. Chemical names used: 3-(1-methylethyl)-(1H)-2,1,3-benzothiadiazin-4(3H)-one 2,2-dioxide (bentazon); 2-[4,5-dihydro-4-methyl-4-(1-methylethyl-4-(1-methylethyl)-5-oxo-1Himidazol-2-yl]-5-ethyl-3-pyridinecarboxylic acid (imazethapyr); 2-chloro- $N$-(2-ethyl-6methylphenyl)- $N$-(2-methoxy-1-methylethyl)acetamide (metolachlor); 2-[1(ethoxyimino)butyl]-5-[2-ethylthio)propyl]-3-hydroxy-2-cyclohexen-1-one (sethoxydim).
\end{abstract}

Green lima bean is a major processing crop in the mid-Atlantic region, with 7200 ha planted annually (Tarburton et al., 1999). However, planted acreage and yield have remained constant over the past 20 years. Research on the impact of cropping practices on profitability is lacking and is needed to implement changes to make production more profitable and maintain lima bean as a viable crop in this region.

Enhancing the cost-effectiveness of lima bean production depends on reducing input costs and increasing yields. Weed control is imperative in crop production and can add significant costs. The need to reduce production costs continues to stimulate interest in weed control techniques that reduce herbicide inputs.

Received for publication 15 May 2000. Accepted for publication 29 Oct. 2000. This research was made possible by financial support from Northeastern Integrated Pest Management Grants Program. The authors thank Quintin Johnson and Tracy Wootten for their input on the manuscript and Joanne Whalen for help with insect identification. The cost of publishing this paper was defrayed in part by the payment of page charges. Under postal regulations, this paper therefore must be hereby marked advertisement solely to indicate this fact.

${ }^{1}$ To whom reprint requests should be addressed. E-mail address: sujatha@udel.edu
Several studies have reported yield advantage in legume crops when planted in narrow rows. Research by Blackshaw et al. (1999) with dry bean (Phaseolus vulgaris L.) demonstrated that reduction in row spacing from 69 to $23 \mathrm{~cm}$ increased yield. Park (1993) and Sandoval-Avila et al. (1994) also reported similar effects in common bean (Phaseolus vulgaris L.) and white bean (Phaseolus vulgaris L.). However, white mold [Sclerotinia sclerotiorum (Lib.)] incidence on common bean increased when row width was reduced (Park, 1993). Teasdale and Frank (1983) showed that snap bean (Phaseolus vulgaris L.) planted at row spacings of 15,25 , and $36 \mathrm{~cm}$ produced similar yields, and all yielded $23 \%$ more than $91-\mathrm{cm}$ rows. However, yield increases were inconsistent with narrower row spacing in lima bean (Larson and Peng-Fi Li, 1948; Sirait et al., 1994).

Reducing space between crop rows has also been discussed as a strategy to reduce the need for herbicides (Patriquin, 1988; Teasdale and Frank, 1983). Crops planted in narrow rows require less herbicide for effective weed control than do those planted in wide rows (Forcella et al., 1992). Crops grown in narrow rows (38 $\mathrm{cm}$ or less) shade weed seedlings more effectively than those grown in traditional wide rows $(76 \mathrm{~cm})$ and suppress weed resurgence (Yelverton and Coble, 1991). The enhanced ability of white bean cultivars to reduce weed biomass in medium and narrow rows was demonstrated by Malik et al. (1993). Row spacings of 15 and $36 \mathrm{~cm}$ suppressed weed growth by $18 \%$ relative to $91-\mathrm{cm}$ spacing when weeds were allowed to emerge with snap beans, while weed suppression was $82 \%$ when weeds were controlled during the first half of the season (Teasdale and Frank, 1983).

Weed management is a primary concern of farmers for several reasons. Weeds compete with lima bean for water, nutrients, and light and can reduce yields. Glaze and Mullinix (1984) reported 18\% yield loss in lima bean over a 3-year period with 2.7 sicklepod (Senna obtusifolia L.) plants $/ \mathrm{m}^{2}$.

Weeds reduce raw product recovery by harvesters, generate foreign matter in the harvested product, reduce harvest efficiency, and increase the costs of processing (Glancey et al., 1995). Weeds such as horsenettle (Solanum carolinense L.), eastern black nightshade (Solanum ptycanthum Dun.), and morningglory (Ipomoea sp.) produce berries or seeds similar to lima bean in size or color. The presence of these weed seeds and/or other foreign materials can result in penalties or price reductions to the grower, or even outright rejection of the harvested crop (Kee et al., 1997). Removing weed seeds and plant parts with the cleaning systems on the combines or with color sorters in the processing plant is difficult. At present, the best method to reduce weed seed contamination from the harvested product is an effective weed control program during the growing season (Glancey et al., 1997).

Weeds can also impact deposition and coverage of pesticides on crop foliage (Norris and Kogan, 2000; Royal et al., 1997). Thus, weed management must be integrated with other pest management strategies and cultural practices.

Lima bean growers currently rely on herbicides and cultivation for weed control. Only a few preemergence and two postemergence herbicides (bentazon and sethoxydim) are labeled for lima bean production. These herbicides do not provide broad-spectrum weed control. Research is needed to identify alternative or complementary weed control methods for lima bean production.

Reduced herbicide rates and band application of herbicides have been effective in reducing the total amount of herbicide used in more competitive crops such as corn (Zea mays L.) and soybean [Glycine max (L.) Merr.]. Cultivation used in combination with reduced herbicide rates or band application has improved total weed control in both of these crops (Buhler et al., 1992; DeFelice et al., 1989; Forcella et al., 1992; Mulder and Doll, 1993; Muyonga et al., 1996). Furthermore, cultivation in combination with reduced herbicide rates increased soybean yield and decreased late-season weed populations and seed production (Steckel et al., 1990).

Planting crops such as soybean (Board et al., 1992; Yelverton and Coble, 1991) and cotton (Gossypium hirsutum L.) (Brown et al., 1998 ) in narrow rows (36 cm or less) has increased yield and reduced weed control costs. 
Recently, questions have been raised about growing lima bean in 38-cm rows. Equipment modifications are not necessary, since this planting distance is often used for soybean, but cultivation is not feasible. Therefore, the effect of earlier canopy closure in narrow row lima bean on weed interference needs to be determined. Reduced row spacing has not improved lima bean yields in the mid-Atlantic region (Sirait et al., 1994), but no studies have compared the effects of row spacing on weed management in lima bean. Thus, this study was initiated to evaluate the impact of reduced row spacing on lima bean yield, yield attributes, and quality, and on pest management. An additional objective was to evaluate weed control costs in 38 - vs. $76-\mathrm{cm}$ rows.

\section{Materials and Methods}

Field information. Field experiments were conducted in 1996 and 1997 at the Univ. of Delaware's Warrington Farm (DE) located near Harbeson, Del., and Univ. of Maryland Lower Eastern Shore Research and Education Center (MD) in Salisbury, Md. Soils at the DE sites were an Evesboro loamy sand (mesic coated Typic Quartzipsamments) in 1996 and Downer loamy sand (coarse-loamy, siliceous, mesic, Typic Hapludults) in 1997. Norfolk loamy sand (fine-loamy, siliceous, thermic, Typic Paleudult) was the soil type in MD in both years. Soil pH was 5.4 in DE and 6.4 in MD with $1.2 \%$ and $1 \%$ organic matter, respectively. At planting, $68 \mathrm{~kg} \cdot \mathrm{ha}^{-1}$ of $\mathrm{N}$ was applied in 1996 but none in 1997 in DE and 90 $\mathrm{kg} \cdot \mathrm{ha}^{-1}$ in MD in both years. All sites were irrigated.

Planting date and population. 'Maffei 15' lima bean was used at all sites. Sites in Delaware were seeded on 28 June 1996 and 27 June 1997. Planting dates in Maryland were 13 June 1996 and 16 June 1997. Seeding depth was 2.5 to $3.0 \mathrm{~cm}$. Total plant population with both row spacings was 175,000 plants/ha in 1996 in DE and in both years in MD. In 1997, plant population in DE was $175,000 /$ ha in $76-\mathrm{cm}$ rows and $350,000 /$ ha in $38-\mathrm{cm}$ rows.

Plot size. In DE, plot size was $3 \mathrm{~m}$ wide in both years and $213 \mathrm{~m}$ (1996) or $15 \mathrm{~m}$ long (1997). Plots in the 76-cm row spacing contained four rows, plots in the $38-\mathrm{cm}$ rows seven rows. In MD, plots were $6 \mathrm{~m}$ wide $\times 9 \mathrm{~m}$ long and contained 8 and 16 rows for the 76and $38-\mathrm{cm}$ row spacing systems, respectively. In DE, in 1996, a 23-m-long area within each plot of both row systems was flagged and left unsprayed to serve as a nontreated check; this area was randomly placed within each plot to reduce variation. In 1997, plot size was reduced and separate plots were maintained for nontreated checks. In MD, nontreated check plots were separately maintained in both years.

Treatments. The treatments in the $76-\mathrm{cm}$ row system consisted of $1.0 \mathrm{X}$ or $0.5 \mathrm{X}$ herbicide rates applied either broadcast or banded, and a nontreated check (cultivated). Three treatments were applied in the $38-\mathrm{cm}$ row system [1.0X or $0.5 \mathrm{X}$ herbicides applied broadcast and a nontreated check (not cultivated)].
Thus, the total number of treatments evaluated was eight.

Herbicide application. A tank-mixture of metolachlor plus imazethapyr was eitherbroadcast or banded at $1 \mathrm{X}$ and $0.5 \mathrm{X}$ rates preemergence. All rates are expressed as a.i. The $1 \mathrm{X}$ rates were metolachlor at $1.5 \mathrm{~kg} \cdot \mathrm{ha}^{-1}$ and imazethapyr at $0.05 \mathrm{~kg} \cdot \mathrm{ha}^{-1}$. This is the most common preemergence herbicide combination for lima bean production in the midAtlantic region. The $38-\mathrm{cm}$ rows received a broadcast application only, while the $76-\mathrm{cm}$ rows received a broadcast or band application as mentioned above. Band width was $25 \mathrm{~cm}$, centered over the crop row. Thus, banded treatments received $33 \%$ or $17 \%$ of the broadcast herbicide rates. Irrigation of $\approx 1.5 \mathrm{~cm}$ was applied within $24 \mathrm{~h}$ of herbicide application. Thereafter, irrigation was applied as needed to maintain adequate soil moisture. All plots containing 76-cm rows, including nontreated checks, were cultivated once in DE (22 DAP in 1996, 40 DAP in 1997) and twice in MD (20 and 34 DAP in 1996, 21 and 36 DAP in 1997). Prolonged wet weather delayed cultivation in DE in 1997.

Data recorded. Plant height, crop canopy width, and number of nodes per plant were measured nondestructively on five plants at random locations in the center two rows of the $76-\mathrm{cm}$ rows and four rows of $38-\mathrm{cm}$ rows. The measurements began at the second trifoliate stage and were repeated on the same plants at 10-d intervals until pod fill.

Destructive samplings were taken at three randomly chosen areas using a quadrat of $18 \times$ $150 \mathrm{~cm}$ at the second trifoliate, late bloom, and preharvest stages of lima bean growth. The quadrat was laid perpendicular to the row and all weeds within the quadrats were separated by species, counted, harvested, and dried to a constant weight. Bean plants were harvested within the sample areas for determination of above-ground biomass. Visual evaluations of weed control were made on the same dates as destructive samplings in 1997, based on a scale of 0 to 100 , where 0 represented no control and 100 was complete control.

Plots were surveyed for insects and diseases at each nondestructive sampling date. Insects were sampled and counted by species according to prescribed scouting procedures.

At harvest, 10 randomly selected lima bean plants were harvested and the numbers of total pods, plump pods, and flat pods were determined both years in MD, but only in 1997 in DE. Number of pods containing one, two, three, or four seeds was determined for all pods on 10 plants.

A 6-m-long area from the center two (76$\mathrm{cm}$ row) or four rows (38-cm row) was harvested for final yield. Pods were mechanically threshed and bean weight per plot was recorded. A 600-g threshed bean sample was passed through a sieve (95-mm-diameter holes), and the weight of beans retained after sieving and those that passed through the sieve were recorded separately. Weight of beans not removed by sieving is a measure of marketable yield. Two-hundred shelled seeds were counted from the seeds that were retained after sieving and weighed. Finally, 200 shelled seeds were examined for insect damage and pod rot (caused by Rhizoctonia solani Kuhn.). Seeds with pod rot symptoms were surface-sterilized and placed on acidified potato dextrose agar to verify that Rhizoctonia solani was present. Data on weight of lima beans retained after sieving and seed damage served as indicators of quality.

Economic analysis. An economic analysis was conducted using a partial budgeting technique to evaluate the profitability of lima bean production with different row spacings and weed management inputs (Lessley et al., 1997). Costs of herbicide, herbicide application, application method, and cultivation, which would impact the decision to adopt a particular spacing, were deducted from net income. Selling price was assumed to be $\$ 0.35 / \mathrm{kg}$. Other costs were metolachlor $\$ 16.2 / \mathrm{L}$, imazethapyr $\$ 158.2 / \mathrm{L}$, herbicide application $\$ 15 /$ ha (broadcast or band), and one cultivation $\$ 30 /$ ha (Univ. of Delaware, 1997).

Data analysis. The experimental design was a randomized complete block with each treatment replicated four times. All data were subjected to analysis of variance and orthogonal contrasts were used to analyze the differences among treatments [ $76 \mathrm{vs} .38 \mathrm{~cm} ; 1 \mathrm{X}$ vs. $0.5 \mathrm{X}$ (broadcast application only in both row spacings); broadcast vs. band (76 cm only); herbicide vs. no herbicide; and cultivation vs. no cultivation]. Transformation of the data did not improve data analysis, thus nontransformed data were used for all analyses.

\section{Results and Discussion}

Because of significant $(P \leq 0.05)$ year $\times$ location interactions, data are presented separately for each year and location.

Bean plant measurements. At both locations, treatments other than row spacing had no effect on plant height, canopy width, or number of nodes per plant (data not shown). However, plants in 38-cm rows were erect and more upright in habit than those in $76-\mathrm{cm}$ rows.

Row spacing had no effect on biomass production in DE in either year, whereas it influenced crop biomass in MD in 1996 only (Table 1). Differences between check and all other treatments were significant. At both locations and years, biomass was $1.5 \mathrm{X}$ to $4 \mathrm{X}$ lower in check plots. At both locations and years, dry matter production in the 76-cm rows was not affected by method or rate of application of herbicides. Cultivation had an effect on biomass production in only one of the four experiments.

White mold, root rot, pod rot, and stem anthracnose [caused by Colletotrichum lindemuthianum (Sacc. \& Magnus) Lams.Scrib] are the major diseases in lima bean, while corn earworm [Helicoverpa zea (Boddie)], European corn borer [Ostrinia nubilalis (Hubner)], Mexican bean beetle [Epilachna varivestis (Mulsant)], and green stinkbug (Nezara viridula L.) are the major insect pests. Disease symptoms were not found on bean foliage at any of the sites. At both 
locations in each year, row spacing, weed management inputs, or herbicide application method had no effect on insect populations (data not shown). Although some pod rot infestation was observed on shelled beans (data not shown), there were no foliar symptoms of disease.

Weed control. Carpetweed (Mollugo verticillata L.), ivy morningglory [Ipomoea hederacea (L.) Jacq.], common purslane (Portulaca oleracea L.), and fall panicum (Panicum dichotomiflorum Michx.) were the dominant weed species in DE. Dominant weed species in MD were carpetweed, common purslane, large crabgrass [Digitaria sanguinalis (L.) Scop.], and fall panicum.

At both locations, measurements of weed density are presented only for the bloom stage of lima bean. Differences in weed density existed between the two row spacings in 1996 in DE and in 1997 in MD (Table 2). Heavy weed pressure in the $38-\mathrm{cm}$ rows in 1996 in DE and in 1997 in MD led to the differences between the two row spacings. Cultivation reduced weed densities in the $76-\mathrm{cm}$ rows (Table 2). Except in 1997 in DE, both 1X and $0.5 \mathrm{X}$ broadcast herbicide rates had similar effects in reducing weed density at both locations (Table 2). A similar trend was observed with broadcast vs. band applications in 76-cm rows.

In DE and MD, weed control was similar in both row spacings regardless of herbicide rate or application method (data not shown). Fall panicum control in DE and fall panicum and crabgrass control in MD were improved (because of cultivation) when $76-\mathrm{cm}$ rows were used (data not shown).

Weed biomass production trends were similar at both locations (Table 2). Except for nontreated checks, no differences were observed among the rest of the treatments in the two row spacings. Reduction in biomass production of weeds in both 38- and 76-cm rows was similar when herbicides were applied at labeled or reduced rates and either broadcast or banded in 76-cm rows. Orthogonal contrasts showed that the benefit of one or two cultivations of 76-cm rows during the vegetative stages did not last through harvest. As a result, no differences in weed biomass were observed between row spacings.

Lima bean yield attributes. Row spacing or the weed management inputs did not impact number of pods with $1,2,3$, or 4 beans (data not shown). However, row spacing had a significant impact on the number of total and plump pods at both locations and in both years (Table 3).

In DE, total and plump pods per 10 plants were higher in $76-\mathrm{cm}$ rows than in $38-\mathrm{cm}$ rows (Table 3), but the effects of method and rate of herbicide application on total or plump pod production were not significant within row spacings. Cultivation increased pod production at both sites in 1996 .

In MD, pod production was greater in 38than in $76-\mathrm{cm}$ rows (Table 3 ), but was not affected by herbicide rate or method of application. In both 1996 and 1997, numbers of flat (unfilled) pods were higher in 76- than in 38$\mathrm{cm}$ rows (data not shown).

Table 1. Dry matter production of lima bean plants as affected by weed control treatments in Delaware and Maryland. ${ }^{2}$

\begin{tabular}{|c|c|c|c|c|c|c|}
\hline \multirow{2}{*}{$\begin{array}{l}\text { Row } \\
\text { spacing } \\
(\mathrm{cm})\end{array}$} & \multicolumn{2}{|c|}{$\begin{array}{c}\text { Herbicide } \\
\text { application }^{\mathrm{y}}\end{array}$} & \multicolumn{2}{|c|}{ Delaware } & \multicolumn{2}{|c|}{ Maryland } \\
\hline & Method & $\overline{\text { Rate }}$ & 1996 & 1997 & 1996 & 1997 \\
\hline & & & & Dry ma & $\mathrm{g} / \mathrm{plan}$ & \\
\hline \multirow[t]{5}{*}{76} & \multirow[t]{2}{*}{ Broadcast } & $1 \mathrm{X}$ & 36 & 39 & 25 & 41 \\
\hline & & $0.5 \mathrm{X}$ & 37 & 35 & 21 & 38 \\
\hline & \multirow[t]{2}{*}{ Band } & $1 X$ & 32 & 35 & 24 & 46 \\
\hline & & $0.5 \mathrm{X}$ & 34 & 27 & 30 & 43 \\
\hline & \multicolumn{2}{|l|}{ None } & 12 & 22 & 13 & 16 \\
\hline \multirow[t]{3}{*}{38} & \multirow[t]{2}{*}{ Broadcast } & $1 \mathrm{X}$ & 25 & 25 & 36 & 49 \\
\hline & & $0.5 \mathrm{X}$ & 30 & 25 & 33 & 47 \\
\hline & \multicolumn{2}{|l|}{ None } & 7 & 17 & 11 & 12 \\
\hline \multicolumn{7}{|c|}{ Paired comparisons } \\
\hline & \multicolumn{2}{|c|}{$76-\mathrm{cm}$ vs. $38-\mathrm{cm}$} & NS & NS & $*$ & NS \\
\hline & \multicolumn{2}{|c|}{$1 \mathrm{X}$ vs. $0.5 \mathrm{X}$} & NS & NS & NS & NS \\
\hline & \multicolumn{2}{|c|}{ Broadcast vs. band } & NS & NS & NS & NS \\
\hline & \multirow{2}{*}{\multicolumn{2}{|c|}{$\begin{array}{l}\text { Herb. vs. no herb. } \\
\text { Cult. vs. no cult. }\end{array}$}} & $*$ & $*$ & $*$ & $*$ \\
\hline & & & NS & NS & $*$ & NS \\
\hline
\end{tabular}

${ }^{\mathrm{z}} \mathrm{At}$ both locations and years, dry matter production was recorded prior to harvest. ${ }^{\mathrm{y}}$ Herbicide applications comprised of $1 \mathrm{X}$ or $0.5 \mathrm{X}$ rates of metolachlor and imazethapyr applied preemergence at 1.5 and $0.05 \mathrm{~kg} \cdot \mathrm{ha}^{-1}$, respectively $(=1 \mathrm{X}$ rate $)$, as either broadcast spray or in $25-\mathrm{cm}$ band. Only $76-\mathrm{cm}$ rows were cultivated, once in Delaware and twice in Maryland in both years.

Ns, * Nonsignificant or significant at $P \leq 0.05$.

Table 2. Density ${ }^{z}$ and dry matter production ${ }^{y}$ of weeds as influenced by various treatments in 1996 and 1997 in Delaware and Maryland.

\begin{tabular}{|c|c|c|c|c|c|c|c|c|c|c|}
\hline \multirow{2}{*}{$\begin{array}{l}\text { Row } \\
\text { spacing } \\
(\mathrm{cm})\end{array}$} & \multicolumn{2}{|c|}{$\begin{array}{c}\text { Herbicide } \\
\text { application }\end{array}$} & \multicolumn{2}{|c|}{ Delaware } & \multicolumn{2}{|c|}{ Maryland } & \multicolumn{2}{|c|}{ Delaware } & \multicolumn{2}{|c|}{ Maryland } \\
\hline & Method & Rate & 1996 & 1997 & 1996 & 1997 & 1996 & 1997 & 1996 & 1997 \\
\hline & & & 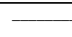 & No. we & $\mathrm{ds} / \mathrm{m}^{2 \mathrm{w}}$ & $\bar{z}$ & $-\mathrm{We}$ & dry $u$ & ight $(\mathrm{g}$ & $2)^{\mathrm{w}-}$ \\
\hline \multirow[t]{5}{*}{76} & Broadcast & $1 \mathrm{X}$ & 1 & 1 & 8 & 1 & 8 & 3 & 2 & 2 \\
\hline & & $0.5 \mathrm{X}$ & 3 & 4 & 31 & 3 & 14 & 31 & 4 & 6 \\
\hline & Band & $1 X$ & 11 & 6 & 26 & 28 & 10 & 28 & 7 & 96 \\
\hline & & $0.5 \mathrm{X}$ & 7 & 25 & 24 & 12 & 29 & 53 & 17 & 37 \\
\hline & None & & 22 & 20 & 58 & 89 & --- & 128 & 321 & 530 \\
\hline \multirow[t]{3}{*}{38} & Broadcast & $1 \mathrm{X}$ & 17 & 4 & 19 & 25 & 20 & 19 & 3 & 3 \\
\hline & & $0.5 \mathrm{X}$ & 43 & 9 & 32 & 121 & 21 & 33 & 30 & 5 \\
\hline & None & & 336 & 17 & 179 & 238 & --- & 189 & 540 & 567 \\
\hline \multicolumn{11}{|c|}{ Paired comparisons } \\
\hline & \multicolumn{2}{|c|}{$76 \mathrm{~cm}$ vs. $38 \mathrm{~cm}$} & $*$ & NS & NS & $*$ & NS & NS & NS & NS \\
\hline & \multicolumn{2}{|c|}{$1 \mathrm{X}$ vs. $0.5 \mathrm{X}$} & NS & $*$ & NS & NS & NS & NS & NS & NS \\
\hline & \multicolumn{2}{|c|}{ Broadcast vs. band } & NS & $*$ & NS & NS & NS & NS & NS & NS \\
\hline & \multicolumn{2}{|c|}{ Herb. vs. no herb. } & $*$ & $*$ & $*$ & $*$ & --- & $*$ & $*$ & $*$ \\
\hline & \multicolumn{2}{|c|}{ Cult. vs. no cult. } & $*$ & NS & NS & $*$ & --- & NS & $*$ & NS \\
\hline
\end{tabular}

${ }^{\mathrm{z}}$ Weed density $=$ total no. of broadleaf and grass weeds present during bloom stage of lima bean.

${ }^{y}$ At both locations, dry matter production of weeds was recorded prior to harvest in both years. Weed biomass was not collected from untreated check plots in 1996 in Delaware.

${ }^{x}$ Herbicide applications comprised of $1 \mathrm{X}$ or $0.5 \mathrm{X}$ rates of metolachlor and imazethapyr applied preemergence at 1.5 and $0.05 \mathrm{~kg} \cdot \mathrm{ha}^{-1}$, respectively (= $1 \mathrm{X}$ rate), as either broadcast spray or in $25-\mathrm{cm}$ band. Only 76-cm spaced rows were cultivated, once in Delaware and twice in Maryland in both years, by the time weed densities were recorded.

"Predominant weed species were carpetweed, ivy morningglory, common purslane, and fall panicum in Delaware and carpetweed, common purslane, large crabgrass, and fall panicum in Maryland.

ss, *Nonsignificant or significant at $P \leq 0.05$.

Lima bean yield. In both years and sites, yield was increased $1.5 \mathrm{X}$ to $3 \mathrm{X}$ by weed control treatments at both row spacings (Table 4). Higher yield in 76- than in $38-\mathrm{cm}$ rows in DE reflected the higher number of plump and total pods in the former (Table 4). However, orthogonal contrasts revealed no yield differences between the two row spacings. Herbicide rate, method of application, and cultivation had no significant impact on yield.

In MD, yield was higher in 38- than in 76$\mathrm{cm}$ rows in 1996, but the difference was not significant in 1997 (Table 4). However, yield was similar in all plots with $76-\mathrm{cm}$ rows re- gardless of application method and herbicide rate, and in $38-\mathrm{cm}$ rows regardless of herbicide rate.

In MD, plots were cultivated the second time in 1997, such that the tractor tires ran on alternate rows, while the tires ran between rows in 1996. This may have contributed to some root and foliar damage in 1996, leading to reduced plant biomass in $76-\mathrm{cm}$ rows (Table $1)$. In addition, the second cultivation was performed while plants were flowering and may have increased flower abortion. This may also explain the reduction in pod production (Table 3). In general, early flowers form plump 
Table 3. Pod number ${ }^{2}$ per lima bean plant as influenced by weed control treatments and row spacing in Delaware and Maryland.

\begin{tabular}{|c|c|c|c|c|c|c|c|c|}
\hline \multirow{3}{*}{$\begin{array}{l}\text { Row } \\
\text { spacing } \\
(\mathrm{cm})\end{array}$} & \multirow{2}{*}{\multicolumn{2}{|c|}{$\begin{array}{c}\text { Herbicide } \\
\text { application }^{y}\end{array}$}} & \multirow{2}{*}{\multicolumn{2}{|c|}{$\begin{array}{c}\text { Delaware } \\
1997\end{array}$}} & \multicolumn{4}{|c|}{ Maryland } \\
\hline & & & & & \multicolumn{2}{|c|}{1996} & \multicolumn{2}{|c|}{1997} \\
\hline & Method & Rate & Pods: Total & Plump & Total & Plump & Total & Plump \\
\hline \multirow[t]{5}{*}{$\overline{76}$} & Broadcast & $1 \mathrm{X}$ & 28 & 27 & 19 & 16 & 23 & 22 \\
\hline & & $0.5 \mathrm{X}$ & 28 & 27 & 15 & 13 & 22 & 21 \\
\hline & Band & $1 X$ & 20 & 19 & 19 & 17 & 24 & 23 \\
\hline & & $0.5 \mathrm{X}$ & 28 & 27 & 18 & 16 & 23 & 23 \\
\hline & None & & 22 & 22 & 12 & 10 & 10 & 10 \\
\hline \multirow[t]{3}{*}{38} & Broadcast & $1 \mathrm{X}$ & 17 & 16 & 29 & 26 & 28 & 28 \\
\hline & & $0.5 \mathrm{X}$ & 16 & 16 & 29 & 26 & 27 & 27 \\
\hline & None & & 15 & 14 & 3 & 1 & 4 & 4 \\
\hline \multicolumn{9}{|c|}{ Paired comparisons } \\
\hline & \multicolumn{2}{|c|}{$76-\mathrm{cm}$ vs. $38-\mathrm{cm}$} & * & * & * & * & * & * \\
\hline & \multicolumn{2}{|c|}{$1 \mathrm{X}$ vs. $0.5 \mathrm{X}$} & NS & NS & NS & NS & NS & NS \\
\hline & \multirow{2}{*}{\multicolumn{2}{|c|}{ Broadcast vs. band }} & NS & NS & NS & NS & NS & NS \\
\hline & & & $*$ & $*$ & $*$ & $*$ & $*$ & $*$ \\
\hline & \multicolumn{2}{|c|}{$\begin{array}{l}\text { Herb. vs. no herb. } \\
\text { Cult. vs. no cult. }\end{array}$} & $*$ & $*$ & $*$ & $*$ & NS & NS \\
\hline
\end{tabular}

${ }^{2}$ Averages for 10 plants. In Delaware, yield attributes were measured in 1997 only.

${ }^{y}$ Herbicide applications comprised of $1 \mathrm{X}$ or $0.5 \mathrm{X}$ rates of metolachlor and imazethapyr applied preemergence at 1.5 and $0.05 \mathrm{~kg} \cdot \mathrm{ha}^{-1}$, respectively $(=1 \mathrm{X}$ rate), as either broadcast spray or in $25-\mathrm{cm}$ band. Only $76-$ $\mathrm{cm}$ spaced rows were cultivated, once in Delaware and twice in Maryland in both years by the time weed densities were recorded.

Ns, "Nonsignificant or significant at $P \leq 0.05$.

Table 4. Lima bean yield and returns ${ }^{2}$ as influenced by weed control treatments and row spacing in 1996 and 1997 in Delaware and Maryland.

\begin{tabular}{|c|c|c|c|c|c|c|c|c|c|c|}
\hline \multirow{2}{*}{$\begin{array}{l}\text { Row } \\
\text { spacing } \\
(\mathrm{cm})\end{array}$} & \multicolumn{2}{|c|}{$\begin{array}{c}\text { Herbicide } \\
\text { application }\end{array}$} & \multicolumn{2}{|c|}{ Delaware } & \multicolumn{2}{|c|}{ Maryland } & \multicolumn{2}{|c|}{ Delaware } & \multicolumn{2}{|c|}{ Maryland } \\
\hline & Method & Rate & 1996 & 1997 & 1996 & 1997 & 1996 & 1997 & 1996 & 1997 \\
\hline \multirow{5}{*}{76} & \multirow{3}{*}{ Broadcast } & & \multicolumn{4}{|c|}{ Yield $\left(\mathrm{kg} \cdot \mathrm{ha}^{-1}\right)_{-}$} & \multicolumn{4}{|c|}{ Return (U.S. $\left.\$ / h^{x}\right)^{x}$} \\
\hline & & $1 X$ & 3200 & 3154 & 1026 & 1009 & 1026 & 1009 & 642 & 1419 \\
\hline & & $0.5 \mathrm{X}$ & 3018 & 3044 & 991 & 914 & 991 & 914 & 585 & 1414 \\
\hline & Band & $1 X$ & 3047 & 2954 & 972 & 939 & 972 & 939 & 699 & 1369 \\
\hline & & $0.5 \mathrm{X}$ & 2828 & 2520 & 924 & 815 & 924 & 815 & 882 & 1387 \\
\hline \multirow{4}{*}{38} & None & & 1712 & 1775 & 1219 & 1148 & 574 & 597 & 375 & 350 \\
\hline & Broadcast & $1 \mathrm{X}$ & 3049 & 2798 & 3633 & 4328 & 1002 & 999 & 1222 & 1470 \\
\hline & & $0.5 \mathrm{X}$ & 2860 & 2803 & 3343 & 4212 & 965 & 999 & 1148 & 1458 \\
\hline & None & & 1145 & 2226 & 136 & 445 & 404 & 786 & 49 & 159 \\
\hline \multicolumn{11}{|c|}{ Paired comparisons } \\
\hline & \multicolumn{2}{|c|}{$76-\mathrm{cm}$ vs. $38-\mathrm{cm}$} & NS & NS & $*$ & NS & NS & NS & $*$ & NS \\
\hline & \multicolumn{2}{|c|}{$1 \mathrm{X}$ vs. $0.5 \mathrm{X}$} & NS & NS & NS & NS & NS & NS & NS & NS \\
\hline & \multirow{3}{*}{\multicolumn{2}{|c|}{$\begin{array}{l}\text { Broadcast vs. band } \\
\text { Herb. vs. No herb. } \\
\text { Cult. vs. No cult. }\end{array}$}} & NS & NS & NS & NS & NS & NS & NS & NS \\
\hline & & & $*$ & $*$ & $*$ & $*$ & * & $*$ & $*$ & $*$ \\
\hline & & & NS & NS & NS & $*$ & NS & NS & $*$ & NS \\
\hline
\end{tabular}

${ }^{2}$ Returns were determined by partial budgeting technique. Partial budget analysis was done by deducting only the costs of herbicide, application, and cultivation from net income. All the other expenses of lima bean production were assumed to be constant across all treatments.

${ }^{\mathrm{y}} \mathrm{Herbicide}$ applications comprised of $1 \mathrm{X}$ or $0.5 \mathrm{X}$ rates of metolachlor and imazethapyr applied preemergence at 1.5 and $0.05 \mathrm{~kg} \cdot \mathrm{ha}^{-1}$, respectively ( $=1 \mathrm{X}$ rate), as either broadcast spray or in $25-\mathrm{cm}$ band. Only $76-$ $\mathrm{cm}$ spaced rows were cultivated, once in Delaware and twice in Maryland in both years.

${ }^{x}$ Costs: metolachlor: $\$ 16.2 / \mathrm{L}$; imazethapyr: $\$ 158.2 / \mathrm{L}$; cultivation: $\$ 30 /$ ha once; herbicide application: $\$ 15 /$ ha (broadcast and band). Lima bean selling price was $\$ 0.35 / \mathrm{kg}$.

ss, "Nonsignificant or significant at $P \leq 0.05$.

pods. Thus, increased floral abortion at early flowering because of cultivation may account for lower pod production and lower yield of 76-cm rows in MD in 1996.

Herbicide use on 76-cm rows increased yield 715 to $3205 \mathrm{~kg} \cdot \mathrm{ha}^{-1}$ in comparison with cultivation alone (Table 4); this increase was 1443 to $3883 \mathrm{~kg} \cdot \mathrm{ha}^{-1}$ in $38-\mathrm{cm}$ rows. This suggests that narrow row spacing may compensate for reducing or eliminating cultivation in lima bean.

Seed characteristics. At both locations, row spacing did not affect the weights of seeds retained on the sieve, or of those that fell through, or weight per seed (data not shown).
The increase in pod rot observed in 76- $\mathrm{cm}$ rows indicates that plants that grow upright may have a lower incidence of disease. Mack and Hatch (1968) also reported that snap bean cultivars OSU 949 and SRS 1502, which tend to fall over on the ground, were more subject to white mold. Breeding for plant types with upright architecture and with pods higher on the plant may help control soil-borne plant pathogens. Currently, many infected pods are not harvested because they are borne low on the plant. If harvest efficiency improves, pod rot may become an important disease problem.

Overall level of insect feeding on shelled beans was very low and was not affected by row spacing, herbicide rate, or application method (data not shown).

Economic analysis. Return on investment was higher when weed control measures were adopted (Table 4). In both years in DE, except for untreated checks, returns were similar from both row spacing systems regardless of weed management practices. In MD, profit was $2 \mathrm{X}$ to $8 \mathrm{X}$ as great for $76-\mathrm{cm}$ rows that were cultivated twice with no herbicides applied (untreated check) than for $38-\mathrm{cm}$ rows that were not cultivated (Table 4 ). When herbicides were used, returns were higher from the 38 -cm rows in 1996. Neither herbicide rate nor application method affected returns in $76-\mathrm{cm}$ rows. In 1997, row spacing did not affect returns.

The results from these studies indicate that yield and economic return from lima bean was not affected by row spacing (38 vs. $76 \mathrm{~cm}$ ). Use of herbicides alone without cultivation was sufficient to prevent yield reduction due to weed competition in 38 -cm rows. However, consistency of weed control was better in 76cm rows.

Reduced rates of metolachlor plus imazethapyr, either as a broadcast or banded preemergence application, resulted in weed control, yield, and economic returns equivalent to those obtained with full rates regardless of row spacing. Our findings are in agreement with those of others working with soybean. Field and Nkumbala (1986) reported that pod yields of green beans (Phaseolus vulgaris cv. Gallatin 50) did not differ between row spacings of 15 and $38 \mathrm{~cm}$. Field studies conducted by Muyonga et al. (1996) at two locations in Missouri with $1 \mathrm{X}$ or $0.5 \mathrm{X}$ herbicide rates as preplant incorporated treatments, with or without cultivation, showed that weed control and soybean yields were equivalent regardless of herbicide rate. When only $25 \%$ to $50 \%$ of recommended herbicide rates were used in soybean, weed control was more consistent in $25-$ and $38-\mathrm{cm}$ rows $(82 \%$ to $99 \%$ ), but variable in $76-\mathrm{cm}$ rows ( $42 \%$ to $99 \%$ ). Forcella et al. (1992) reported that soybean yields from $25-$ and $38-\mathrm{cm}$ rows with reduced herbicide treatments (25\% to $50 \%$ of standard label rate) were similar to those in $76-\mathrm{cm}$ rows with $100 \%$ of the recommended herbicide rates.

Although full rates of herbicides used in this study were as effective as reduced rates in controlling weeds, we speculate that differences would have existed had the seeds been planted in early May rather than in June. Our 
previous research (Sankula and VanGessel, unpublished data) suggested that planting date was a significant factor in the lima bean-weed competition and that May planting increased the weed competitive ability and biomass production of weeds.

Research by Yelverton and Coble (1991) on soybean indicated that weed resurgence was higher in 91- than in 23-cm rows. Reducing the amount of sunlight reaching the ground between rows can suppress weed resurgence. Similar results were reported by Gunsolus et al. (1990). Lima bean is not as competitive as soybean, and therefore the canopy closure in $38-\mathrm{cm}$ rows was not sufficient to prevent weed resurgence (Table 1). Although the effect of cultivation on various parameters was inconsistent, these data show the ineffectiveness of narrow rows as a replacement for cultivation in a less-competitive crop.

There appears to be no advantage to planting lima bean in $38-\mathrm{cm}$ rows. In addition to no yield advantage, $38-\mathrm{cm}$ rows make cultivation difficult. Even at full rates of herbicides, weed escapes may be severe enough at times to necessitate cultivation. Cultivation is one viable measure to improve weed control with soil-applied treatments, and improved the consistency of weed control at the $0.5 \mathrm{X}$ rate of herbicide application.

Based on our results, switching from chemical-intensive systems to low use-rate systems, complemented with mechanical weed management, appears to be viable. The use of reduced herbicide rates is compatible with intensive-management, integrated-production systems. This information helps in developing tactics for integrated pest management systems in lima bean by reducing the environmental risks of pesticide use without sacrificing profitability.

\section{Literature Cited}

Blackshaw, R.E., H.H. Muendel, and G. Saindon. 1999. Canopy architecture, row spacing, and plant density effects on yield of dry bean (Phaseolus vulgaris) in the absence and pres- ence of hairy nightshade (Solanum saracchoides). Can. J. Plant Sci. 79:663-669.

Board, J.E., M. Kamal, and B.G. Harville. 1992. Temporal importance of greater light interception to increased yield in narrow-row soybean. Agron. J. 84:575-579.

Brown, A.B., T.L. Cole, and K. Edmisten. 1998 Ultra narrow row cotton, p. 28. In: North Carolina farm enterprise budget guidelines. North Carolina Coop. Ext. Serv., Raleigh.

Buhler, D.D., J.L. Gunsolus, and D.F. Ralston, 1992. Integrated weed management techniques to reduce herbicide inputs in soybeans. Agron. J. 84:973-978.

DeFelice, M.S., W.B. Brown, R.J. Aldrich, B.D. Sims, D.T. Judy, and D.R. Guethle. 1989. Weed control in soybeans (Glycine max) with reduced rates of postemergence herbicides. Weed Sci. 37:365-374.

Field, R.J. and S. Nkumbala. 1986. Green beans (Phaseolus vulgaris cv. Gallatin 50): Effects of plant population density on yield and quality. $\mathrm{N}$. Z. J. Expt. Agr. 14:435- 442

Forcella, F., M.E. Westgate, and D.D. Warnes. 1992. Effect of row width on herbicide and cultivation requirements in row crops. Amer. J. Alternative Agr. 7:161-167.

Glancey, J.L., W.E. Kee, and T.L. Wootten. 1997. Machine harvest of lima beans for processing. J. Veg. Prod. 3:59-68.

Glancey, J.L., W.E. Kee, T.L. Wootten, and B.C. Postles. 1995. Harvesting of green peas and lima beans for processing. Proc. Amer. Soc. Agr. Eng. Annu. Mtg. Paper 95-1773.

Glaze, N.C. and B.G. Mullinix, Jr. 1984. Competitive effects of sicklepod on lima beans. Weed Sci. 32:1-3.

Gunsolus, J.L. 1990. Mechanical and cultural weed control in corn and soybeans. Amer. J. Alternative Agr. 5:114-119.

Kee, Jr. W.E., J.L. Glancey, and T.L. Wootten. 1997. The lima bean: A vegetable crop for processing. HortTechnology 7:119-128.

Larson, R.E. and P.-F. Li. 1948. The influence of various row and plant spacings on yield of lima beans. Proc. Amer. Soc. Hort. Sci. 51:479-485.

Lessley, B.V., D.M. Johnson, and J.C. Hanson. 1997. Fact sheet 547. Univ. Maryland Coop. Ext. Serv., College Park.

Mack, H.J and D.L. Hatch. 1968. Effects of plant arrangement and population density on yield of bush snap beans. HortScience 92:418-425.

Malik, V.S., C.J. Swanton, and T.E. Michaels. 1993. Interaction of white bean (Phaseolus vulgaris) cultivars, row spacing, and seed density with annual weeds. Weed Sci. 41:62-68.

Mulder, T.A. and J.D. Doll. 1993. Integrating reduced herbicide use with mechanical weeding in corn (Zea mays). Weed Technol. 7:226-232.

Muyonga, K.C., M.S. DeFelice, and B.D. Sims. 1996. Weed control with reduced rates of four soil-applied soybean herbicides. Weed Sci. 44:148-155

Norris, R.F. and M. Kogan. 2000. Interactions between weeds, arthropod insects, and the natura enemies in managed ecosystems. Weed Sci. 48:94-158.

Park, S.J. 1993. Response of bush and upright plant type selections to white mold and seed yield of common beans grown in various row widths in southern Ontario. Can J. Plant Sci. 73:265-272.

Patriquin, D.G. 1988. Weed control in organic farming systems, p. 303-317. In: M.A. Altieri and M Liebman (eds.). Weed management in agroecosystems: Ecological approaches. CRC Press, Boca Raton, Fla.

Royal, S.S., B.J. Brecke, F.M. Shokes, and D.L Colvin. 1997. Influence of broadleaf weeds on chlorothalonil deposition, foliar disease incidence, and peanut (Arachis hypogaea) yield. Weed Technol. 11:51-58.

Sandoval-Avila, D.M., T.E. Michaels, S.D. Murphy, and C.J. Swanton. 1994. Effect of tillage practice and planting pattern on performance of white bean (Phaseolus vulgaris) in Ontario. Can. J. Plant Sci. 74:801-805.

Sirait, Y., W.G. Pill, and W.E. Kee, Jr. 1994. Lima bean (Phaseolus lunatus L.) response to irrigation regime and plant population density. HortScience 29:71-73.

Steckel, L.E., M.S. DeFelice, and B.D. Sims. 1990. Integrating reduced rates of postemergence herbicides and cultivation for broadleaf weed control in soybeans. Weed Sci. 38:541-545.

Tarburton, J.F., S. Stuchlik-Edwards, T.W. Feurer, and R.R. Bosecker. 2000. Delaware agricultural statistics summary for 1999. Delaware Dept. Agr., Newark.

Teasdale, J.R. and J.R. Frank. 1983. Effect of row spacing on weed competition with snap beans (Phaseolus vulgaris). Weed Sci. 31:81-85.

University of Delaware. 1997. Vegetable and crop budgets, Ext. Circ. \#152. Univ. Delaware Coop. Ext., Newark.

Yelverton, F.H. and H.D Coble. 1991. Narrow row spacing and canopy formation reduces weed resurgence in soybeans (Glycine max). Weed Technol. 5:169-174. 